\title{
ANTI-GBM RAPIDLY PROGRESSIVE GLOMERULONEPHRITIS (SYNDROMA GOODPASTURE): \\ A CASE REPORT
}

Andreja Figurek, Vlastimir Vlatkovic, Dragan Vojvodic, Milorad Grujicic

Clinical centre Banja Luka, Clinic for internal diseases, Banja Luka, Republic of Srpska, Bosnia and Herzegovina

\author{
ANTI-GBM RAPIDNO PROGRESIVNI GLOMERULONEFRITIS \\ (SYNDROMA GOODPASTURE): \\ PRIKAZ SLUČAJA \\ Andreja Figurek, Vlastimir Vlatković, Dragan Vojvodić, Milorad Grujičić \\ Klinički Centar Banja Luka, Klinika za unutrašnje bolesti, Banja Luka, Republika Srpska, Bosna i Hercegovina
}

\section{ABSTRACT}

Goodpasture syndrome is a severe illness caused by the formation of antibodies to the glomerular basement membrane and alveolus with consequential damage to renal and pulmonary function. With current therapy, long-term survival is more than $50 \%$. Before, the mortality was higher than $90 \%$.

In our patient, the disease began as dysuria, continued as anaemic syndrome, and ended with the development of end-stage renal failure.

Immunosuppressive therapy with pulse doses of methylprednisolone and cyclophosphamide has put the disease into remission, but the permanent impairment of renal function remained.

Early diagnosis of Goodpasture syndrome helps preserve renal function and improves patients' survival. In patients who achieve remission, a kidney transplant can be considered. Currently, our patient is awaiting transplantation.

Key words: Goodpasture syndrome; collagen $\alpha 3$ (IV) chain; anti-GBM antibodies; crescentic forms.

\section{INTRODUCTION}

Anti-GBM (glomerular basal membrane) rapidly progressive glomerulonephritis $(\mathrm{GN})$ is a renal disease characterised by damage to the glomerulus that has a progressive and rapid flow, caused by the formation of antibodies on the glomerular basement membrane. As a part of Goodpasture Syndrome, antibodies to the basement membrane of the alveoli could also be generated. Anti-GBM GN as a stand-alone entity occurs in approximately $20-40 \%$ of patients, while in the part Goodpasture syndrome occurs in approximately $60-70 \%$ of the cases.

\section{SAŽETAK}

Goodpasture-ov sindrom je teško oboljenje uzrokovano stvaranjem antitela na bazalnu membranu glomerula $i$ alveola sa posledičnim oštećenjem bubrežne i plućne funkcije. Sa sadašnjom terapijom dugogodišnje preživljavanje je veće od 50\%, a pre toga smrtnost usledovog oboljenja je bila veća od $90 \%$.

Početak bolesti kod našeg pacijenta bile su dizurične tegobe, potom anemijski sindrom, da bi se razvila bubrežna slabost završnog stadijuma.

Imunosupresivna terapija pulsnim dozama Methylprednisolona $i$ Cyclophosphamida, uvela je ovog bolesnika u remisiju bolesti, ali je ostalo trajno oštećenje bubrežne funkcije.

Rano postavljanje dijagnoze Goodpastureovog sindroma omogućava očuvanje funkcije bubrega i povoljno utiče na preživljavanje bolesnika. Kod pacijenata kod kojih je postignuta remisija bolesti može se razmatrati i transplantacija bubrega, pa je i naš pacijent u procesu pripreme za transplantaciju.

Ključne reči: Syndroma Goodpasture; $\alpha 3$ lanac kolagena tip IV; Anti-GBM antitijela; polumjesečaste formacije. 
fractions (obtained by biopsy of the kidney) are correlated with the level of serum creatinine but not to the level of the titer anti-GBM antibodies (2).

After binding anti-GBM antibodies (which are the most common IgG class) to self-antigens, the target antigen is $\alpha 3$ chain of type IV collagen basement membrane $(3,4)$, which attracts leukocytes and causes an immune response. This leads to glomerular capillary damage, with consequent proteinuria, hematuria and renal impairment. It also damages the alveolar capillaries, resulting in laboredlaboured breathing and the coughing up of blood.

More than $90 \%$ of patients survive the acute phase of the illness. Death commonly occurs as a result of infections and pulmonary haemorrhage. In the period prior to immunosuppression and plasmapheresis, mortality of patients with Goodpasture syndrome was more than $90 \%$, while the current therapy long-term survival is greater than $50 \%$ (5).

\section{CASE REPORT}

Our subject was a 44-year-old man who became significantly ill for the first time in January 2011. Because of complaints of dysuria, he was under the constant supervision of a urologist. (His labs were as follows: urea 13.1 $\mathrm{mmol} / \mathrm{l}$, creatinine $168 \mu \mathrm{mol} / \mathrm{l}$, erythrocyte sedimentation rate $60 / 90$, protein in the urine + , and in urine sediment approximately 30 leucocytes and 4-6 erythrocytes.) He was treated by urologists with antibiotics and uroantiseptics. At the end of March 2011, the laboratory findings returned to normal. In a control analysis in December 2011, he had advanced renal failure (urea $23 \mu \mathrm{mol} / \mathrm{l}$, creatinine $686 \mu \mathrm{mol} / \mathrm{l}$, proteinuria +++ , many leucocytes and erythrocytes in urine sediment), followed by anaemia (Hgb 85 $\mathrm{g} / \mathrm{l})$, radiologically enlarged heart shadow at the expense of the left ventricle, hilum extended and he was sent for treatment at our clinic. Upon admission, his main symptoms were headache, occasional dizziness, and frequent, difficult and painful urination. He was afebrile. His skin and mucosa had poor circulation. Heart and lung auscultation obtained normal findings.

With hypoalbuminemia and signs of an inflammatory syndrome, progression of renal failure occurs to the terminal level (creatinine $1.016 \mu \mathrm{mol} / \mathrm{l}$, creatinine clearance of $4.8 \mathrm{ml} / \mathrm{min}$, and diuresis $<200 \mathrm{ml}$ ). Treatment started with hemodialysis, three to four hours each week. Immediately, we obtained a blood sample for immunological examination and a kidney biopsy, which confirmed that it was rapidly progressive GN. (Fig. 1). Immunofluorescence findings showed linear deposits of immunoglobulin G (IgG) along the glomerular basement membrane (Fig. 2), and were foundpositive Anti-GBM, perinuclear anti-neutrophil cytoplasmic antibodies (pANCA) and antinuclear antibodies (ANA) were found using immunological tests (which came later and were why the treatment with plasmapheresis was not immediately begun).

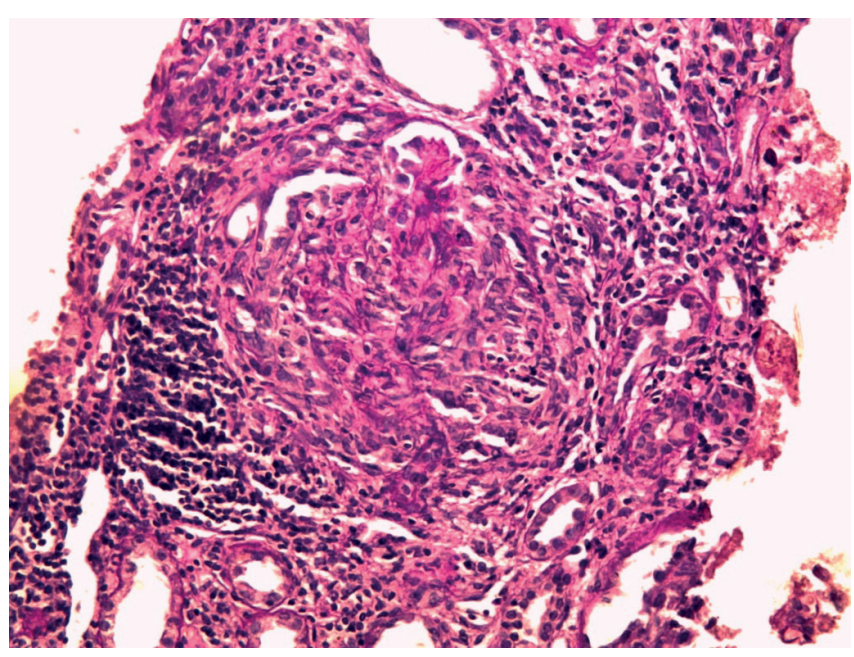

Figure 1. Optical microscopy: cellular crescent presses glomerular vascular bundle, thickening of the GBM

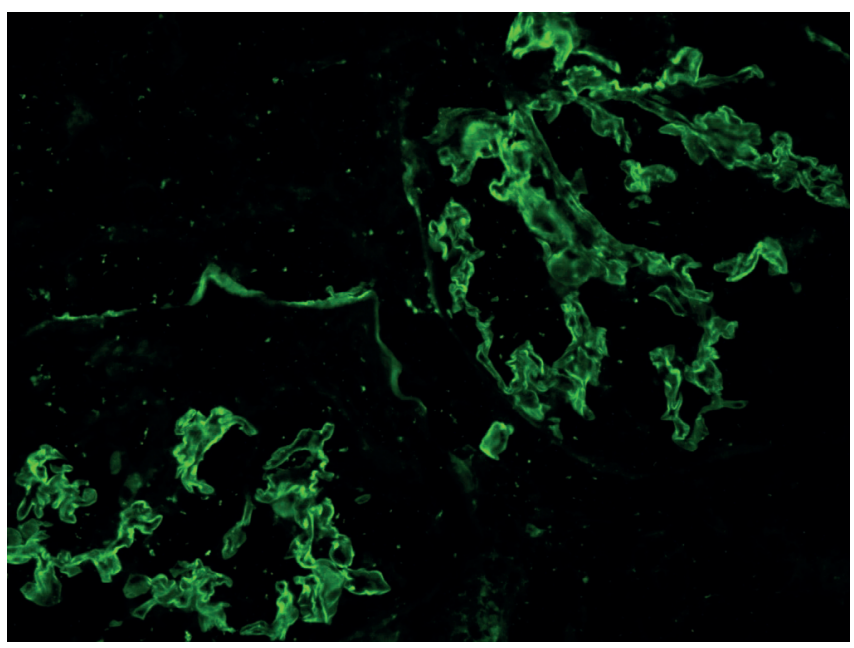

Figure 2. Immunofluorescence: IgG $++/+++$ linearly along the GBM, C3 $+/$ - linearly along the GBM and focal granular in mesangium

At the end of December 2011, the patient received the first pulse of methylprednisolone and cyclophosphamide. The treatment then was continued with prednisone tablets. Then, he developed the clinical picture of unspecified pneumonia, with radiological infiltrative changes that could suit also the primary disease. For this, the patient was treated with three antibiotics (ciprofloxacin, cephalosporin and meropenem), after which there was clinical and laboratory improvement. A complication, pseudomembranous colitis, arose, which was detected by colonoscopy. After the treatment with vancomycin, metronidazole, antifungal and mesalazine, the patient has a formed stool. Then, the treatment was continued with pulse doses of methylprednisolone and cyclophosphamide, followed by prednisone tablets orally starting with $50 \mathrm{mg}$ per day. While receiving two pulses of cyclophosphamide, the patient had a relapse of pseudomembranous colitis, which was treated with metronidazole. The dose of prednisone was reduced gradually to $10 \mathrm{mg}$ per day. After the fifth pulse of cyclophosphamide, there was a reduction in anti-GBM antibodies from the initial level of 698 $\mathrm{U} / \mathrm{ml}$ to levels of $6 \mathrm{U} / \mathrm{ml}$ on the last control. 
In addition to pulmonary and renal manifestations of the disease, a vision impairment can occur as part of Goodpasture syndrome. In our patient, bilateral retinal haemorrhage was found. Since the treatment options progressed and the life of this patient was extended, then it makes sense to include ocular manifestations of the disease in therapy (6)

\section{CONCLUSION}

In our patient, the disease initially manifested itself in the form of dysuric complaints. In less than a year, there was a decline in renal function. Our patient was positive for antiGBM, pANCA and ANA using immune tests; thus, ichGoodpasture syndrome was suspected. Immunochemical properties of autoantibodies do not affect the survival of patients with Goodpasture syndrome, but could be a factor of survival if detected in patients who have not had serious damage to the kidney (7).

If the immunosuppressive therapy is introduced early in the course of the disease, it can prevent or recover renal failure and may result in the cessation of pulmonary haemorrhage in the majority of patients with Goodpasture syndrome (8). Plasmapheresis, as an additional form of treatment, leads to a reduction of complement and fibrinogen, mediators that likely contribute to the damage that is incurred by the influence of autoantibodies (9). In our case, the treatment of plasmapheresis is not applied because there was a significant decrease in anti-GBM antibodies as a response to immunosuppressive therapy.

Patients for whom hemodialysis is immediately indicated have less chance of recovery of renal function (10), as was the case in our patient.

Although Goodpasture syndrome is a rare disease, it is necessary to bear it in mind, considering the weight of the disease. Additionally, it is possible to diagnose the disease at an early stage, due to the availability of immunoassays (such as anti-GBM antibody) and kidney biopsies. Only timely diagnosis (within the first few weeks of the onset of illness) makes a cure possibly. Unfortunately, diagnosis of this syndrome is usually made only when there are signs of renal failure, and then patients are almost always on dialysis (11).
Additionally, kidney transplantation is taken into account as a form of treatment of Goodpasture syndrome, but patients must be negative for anti-GBM antibodies for six months because there is a lower probability of disease transition on the transplanted kidney (less than 5\%). Our patient, thanks to achieved remission, is awaiting a kidney transplantation.

\section{REFERENCES}

1. Rossert J. Goodpasture's disease. Orphanet encyclopedia; 2002.

2. Fisher EG, Lager DJ. Anti-glomerular basement membrane glomerulonephritis: A morphologic study of 80 cases. Am J Pathol 2006; 125: 445-50.

3. Kalluri R, Gattone II VH, Nollken ME et al. The $\alpha 3$ chain of type IV collagen induces autoimmune Goodpasture sy. Proc. Natl.Acad. Sci USA. 1994;91:6201-5.

4. Persson U, Hertz JM, Carlsson M et al. Patients with Goodpasture's disease have two normal COL4A3 alleles encoding the $\mathrm{NC} 1$ domain of the type IV collagen $\alpha 3$ chain. Nephrol Dial Transplant 2004; 19: 2030-5.

5. Panjwani AH, Deoskar RB, Falleiro JJJ et al. Goodpasture Syndrome. MJAFI 2003; 59: 77-9.

6. Rowe PA, Mansfield DC, Dutton GN. Ophthalmic features of fourteen cases of Goodpasture sy. Nephron 1994; 68: 52-6.

7. Segelmark M, Hellmark T, Wieslander J. The Prognostic Significance in Goodpasture's Disease of Specificity, Titre and Affinity of Anti-Glomerular-Basement-Membrane Antibodies. Nephron Clin Pract 2003; 94: 59-68.

8. Briggs WA, Johnson JP, Teichman S, et al. Antiglomerular basement membrane antibody-mediated glomerulonephritis and Goodpasture's syndrome. Medicine (Baltimore) 1979 Sep; 58 (5): 348-61.

9. Lockwood CM, Pearson TA, Rees AJ, et al. Immunosuppression and plasma-exchange in the treatment of Goodpasture's syndrome. The Lancet 1976; 307(7942):711-5.

10. Levy JB, Turner AN, Rees AJ, et al. Long-term outcome of anti-glomerular basement membrane antibody disease treated with plasma exchange and immunosuppression. Ann Intern Med 2001; 134:1033-42.

11. Vučković B, Ilić T, Mitić I, et al. Goodpastureov sindrom prikaz slučaja. Medicinski pregled 2004; 57(7-8):391-5. 